УДК 620.178.162

( Ю. М. Гузенко, к.т.н., доцент, В. С. Олійник, студент, КП। ім. Ігоря Сікорського, Київ, Україна

\title{
МОДЕРНІЗАЦІЯ МАШИНИ ТЕРТЯ \\ ДЛЯ ВИПРОБУВАННЯ МАТЕРІАЛІВ ЗУБЧАСТИХ ПЕРЕДАЧ ДРУКАРСЬКОЇ ТЕХНІКИ
}

У статті розглядається модернізована машина тертя підвищеної точності випробування матеріалів зубчастих передач. Суть модернізації такої машини тертя вирішується використанням в її кінематиці між приводом і роликовими зразками однакового діаметра двох пар ексцентрично закріплених зубчастих коліс. У результаті зазначеного кінематичного зв'язку обох роликових зразків відбувається плавне збільшення і зменшення їх кутових швидкостей на одних ділянках з досягненням однакових кутових швидкостей на других ділянках. У цей час відбувається тертя кочення із зміною відносного проковзування на одних ділянках роликових зразків та тертя кочення без проковзування на других ділянках. Ці режими тертя забезпечують кінематичні умови взаємодії зубців циліндричних зубчастих коліс вздовж ліній своїх зачеплень з різними знаками проковзування. Відповідно, за цих умов значно підвищується точність фізичного моделювання роботи таких зубчастих передач в приводах друкарського обладнання.

Ключові слова: машина тертя; випробування матеріалів; зубчаста передача; кутова швидкість; роликовий зразок; тертя кочення; тертя кочення 3 відносним проковзуванням.

\section{Постановка проблеми}

Переважно для здійснення триботехнічного випробування матеріалів різних зубчастих передач використовують машини тертя, які забезпечують ступінчасту зміну тертя кочення і тертя кочення з відносним проковзуванням роликових зразків однакового діаметра [1, 2]. Однією з них є машина тертя СМЦ-2, яка містить вали для закріплення роликових зразків, привод для їх обертан- ня з ведучими зубчастими колесами, кінематично зв'язаними через дві пружні муфти і датчик моменту тертя з валом для закріплення нижнього роликового зразка, а через пружну муфту і ведені зубчасті колеса - з валом для закріплення верхнього роликового зразка [3].

Змінне тертя кочення роликових зразків встановлюється приводом при частотах їх обертання 300,500 і 1000 хв$^{-1}$, а змінне

() $2017 \mathrm{p}$. 
тертя кочення $з$ відносним проковзуванням забезпечується різними наборами ведених зубчастих коліс при ступінчастому зменшенні на 10, 15 і 20 \% частоти обертання верхнього зразка. У результаті вказаного кінематичного зв'язку ведучих зубчастих коліс машини тертя СМЦ-2 з верхнім зразком забезпечується тільки ступінчаста зміна відносного проковзування обох роликових зразків таких же величин 10, 15 і $20 \%$, а відсутність між ними плавної зміни в межах кожного їх оберту відносного проковзування значно зменшує точність фізичного моделювання умов роботи циліндричних зубчастих передач.

\section{Аналіз попередніх досліджень}

Для випробування матеріалів циліндричних зубчастих передач при терті кочення з плавною зміною відносного проковзування обох роликових зразків однакового діаметра використовують машини тертя, які містять привод для їх обертання з коробкою швидкостей та одною парою ведучих ексцентрично закріплених зубчастих коліс, з'єднаних компенсуючими муфтами з окремими зразками, при цьому коробка швидкостей з'єднана пружною муфтою тільки з одним ексцентрично закріпленим зубчастим колесом [4]. У результаті цього, нижній зразок обертається з постійною кутовою швидкістю, а верхній зразок обертається із плавнозмінним збільшенням і зменшенням кутової швидкості відносно кутової швидкості нижнього зразка.
У межах кожного оберту обох роликових зразків плавнозмінне відносне їх проковзування двічі змінюється від нуля до максимума і від максимума до нуля з випередженням та відставанням верхнього зразка відносно нижнього зразка, при цьому максимальна величина відносного проковзування зразків залежить від величини ексцентриситета ексцентрично закріплених зубчастих коліс. Проте при таких умовах зменшується діапазон і максимальна величина змінного проковзування зразків на кожній зазначеній ділянці.

Відома також здійснена модернізація машини тертя СМЦ-2 за рахунок встановлення допоміжної двоступінчастої зубчастої передачі замість пружної муфти між її ведучими і веденими зубчастими колесами, при цьому зубчаста передача має одну пару співвісно закріплених і другу пару ексцентрично закріплених зубчастих коліс [5]. Окремі співвісно закріплені зубчасті колеса мають радіуси кривизни своїх початкових кіл, які дорівнюють мінімальним і максимальним відстаням від вісей обертання ексцентричних зубчастих коліс до своїх початкових кіл, що дозволяє розширити експлуатаційні можливості машини тертя СМЦ-2 порівняно з другими машинами тертя подібних конструкцій [6] за рахунок збільшення діапазону та максимальної величини відносного проковзування роликових зразків в 2 рази.

Проте вказані режими роботи роликових зразків не забезпечують високу точність триботехнічного випробування матеріалів циліндричних зубчастих 
передач, оскільки плавнозмінне збільшення і зменшення кутової швидкості повинні здійснювати обидва роликові зразки. Таким чином, зі збільшенням кутової швидкості одного роликового зразка повинно відбуватися зменшення кутової швидкості другого зразка, а після досягнення роликовими зразками однакової кутової швидкості між ними повинна здійснюватися протилежна зміна кутових швидкостей із їх зменшенням для одного роликового зразка та збільшенням для другого зразка.

\section{Мета роботи}

Метою роботи є підвищення точності триботехнічного випробування матеріалів циліндричних зубчастих передач шляхом забезпечення на машині тертя плавного збільшення і зменшення кутової швидкості обох її роликових зразків однакового діаметра.

\section{Результати проведених досліджень}

Для досягнення поставленої мети у цій роботі здійснена модернізація машини тертя для випробування матеріалів цилінд- ричних зубчастих передач (рис. 1), яка крім валів 1, 2 для закріплення роликових зразків 3, 4 однакового діаметра, привода 5 для їх обертання та ексцентрично закріплених на валах 6, 7 зубчастих коліс 8, 9, допоміжно містить ексцентрично закріплені на валу 10 зубчасті колеса 11, 12 [7]. Крім цього, всі закріплені на валах 6, 7, 10 зубчасті колеса 8, 9, і 11, 12 виконані з однаковими ексцентриситетами е, a їх величина в кожному конкретному випадку визначається індивідуально залежно від необхідних параметрів плавнозмінного проковзування зразків.

Усі ексцентрично закріплені зубчасті колеса 8, 9, і 11, 12 в одному випадку можуть розташовуватися своїми центрами обертання $\mathrm{O}_{1}, \mathrm{O}_{2}$ і $\mathrm{O}_{3}$ на одній горизонтальній осі MN (рис. 2, а), а в другому випадку зубчасті колеса 8, 9 розташовуються своїми центрами обертання $\mathrm{O}_{2} \mathrm{i} \mathrm{O}_{3} 3$ певними кутовими зміщеннями $\alpha$ від своїх попередніх положень на одній горизонтальній осі MN з центром обертання $\mathrm{O}_{1}$ зубчастих коліс 11, 12 (рис. 2, б), що відповідно дозволяє зменшити

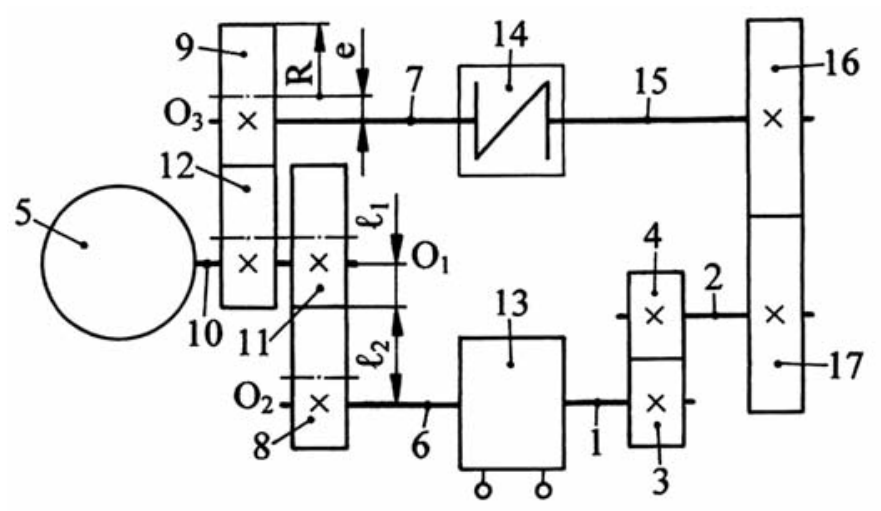

Рис. 1. Кінематична схема модернізованої машини тертя 
міжосьову відстань зубчастих коліс 8, 9. Разом з цим, усі ексцентрично закріплені зубчасті колеса 8, 9, і 11, 12 встановлені так, щоб зубчасте колесо 11 своїми мінімально віддаленими на відстань $\ell_{1}$ зубцями взаємодіяло з максимально віддаленими на відстань $\ell_{2}$ зубцями зубчастого колеса 8 , а зубчасте колесо 12 своїми максимально віддаленими зубцями взаємодіяло з мінімально віддаленими зубцями зубчастого колеса 9.

Спочатку обертальний рух від привода 5 передається на вал 10 з двома ексцентрично закріпленими зубчастими колесами 11,12 , а потім від одного ексцентрично закріпленого на валу 10 зубчастого колеса 11 обертальний рух передається на ексцентрично закріплене на валу 6 зубчасте колесо 8 і через датчик моменту тертя 13 на вал 1 для закріплення роликового зразка 3. Разом з цим від другого ексцентрично закріпленого на валу 10 зубчастого колеса 12 обертальний рух передається на ексцентрично закріплене на валу 7 зубчасте колесо 9 і через пружну муфту 14, вал 15 та зубчасті колеса 16, 17 на вал 2 для закріплення роликового зразка 4.

При виконанні всіх ексцентрично закріплених на валах 6,7 , 10 зубчастих коліс 8, 9, і 11, 12 з однаковими радіусами своїх ділильних кіл $\mathrm{R}=40$ мм та їх ексцентриситетами е $=2$ мм мінімально віддалені зубці розташовані від вісей обертання до ділильних кіл на відстанях $\ell_{1}=38$ мм, а максимально віддалені зубці розташовані на відстанях $\ell_{2}=42 \mathrm{mм}$. Якщо початково для однієї пари зубчастих коліс 8, 11 передатне

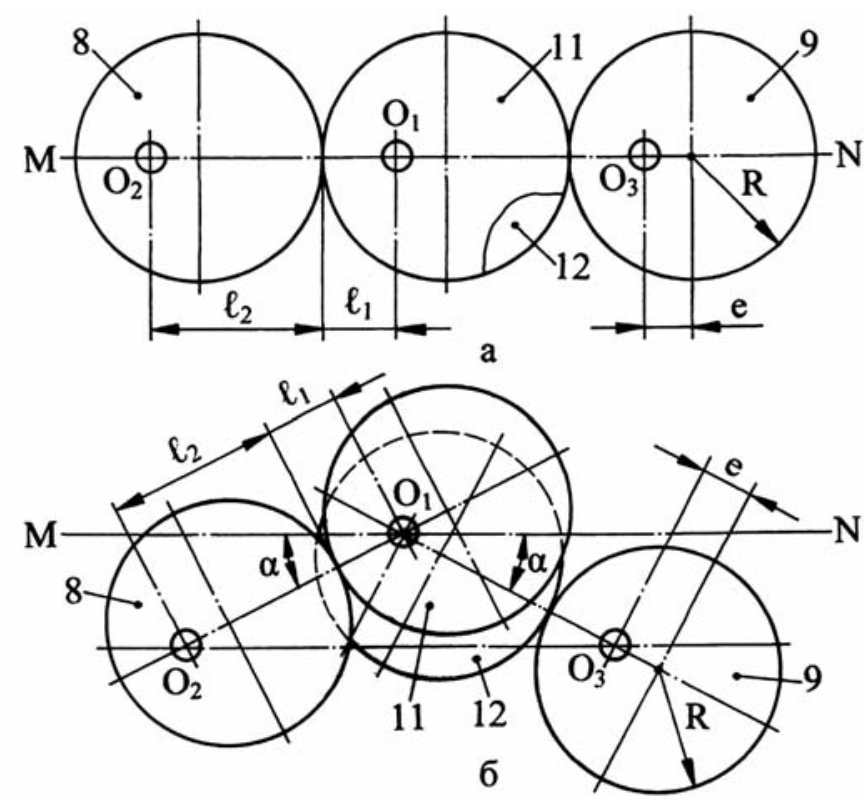

Рис. 2. Варіанти розташування ексцентрично закріплених зубчастих коліс модернізованої машини тертя: a - на одній горизонтальній осі MN; б - із зміщеннями від горизонтальної осі MN 
відношення $\mathrm{i}_{1}=\ell_{2} / \ell_{1}=1,1$, то для другої пари зубчастих коліс 9 , 12 передатне відношення $\mathrm{i}_{2}=$ $=\ell_{1} / \ell_{2}=0,9$. Колова зміна положень зубчастих коліс 8,9 , і 11 , 12 на кут $\varphi^{\circ}=180^{\circ}$ викликає зміну ї передатних відношень на і $\mathrm{i}_{2}=\ell_{1} / \ell_{2}=0,9$ та $\mathrm{i}_{1}=\ell_{2} / \ell_{1}=1,1$, а потім знову через кут $\varphi^{\circ}=180^{\circ}$ на $\mathrm{i}_{1}=\ell_{2} / \ell_{1}=1,1$ та $\mathrm{i}_{2}=\ell_{1} / \ell_{2}=0,9$.

При обертальному русі від привода 5 вала 10 , а також ексцентрично закріплених на ньому зубчастих коліс 11,12 з постійною кутовою швидкістю $\omega_{1}=31,4 \mathrm{c}^{-1}$ (частота ї обертання $\mathrm{n}_{1}=300 \mathrm{xB}^{-1}$ ) вал 6 із своїм ексцентрично закріпленим зубчастим колесом 8 в межах кожного оберту буде плавно змінювати кутову швидкість $\omega_{2}$ від $28,55 \mathrm{c}^{-1}$ до $34,89 \mathrm{c}^{-1}$, а також від $34,89 \mathrm{c}^{-1}$ до $28,55 \mathrm{c}^{-1}$, проходячи кожного разу через $\omega_{2}=31,4 \mathrm{c}^{-1}$. Разом з цим, вал 7 3 аналогічним зубчастим колесом 9 в межах кожного свого оберту буде плавно змінювати кутову швидкість $\omega_{3}$ від $34,89 \mathrm{c}^{-1}$ до $28,55 \mathrm{c}^{-1}$, а також від $28,55 \mathrm{c}^{-1}$ до $34,89 \mathrm{c}^{-1}$, проходячи кожного разу через $\omega_{3}=31,4 \mathrm{c}_{-1}$.

При однакових числах зубців ведених зубчастих коліс 16, 17 та вказаних кутових швидкостях ведучих ексцентрично закріплених зубчастих коліс 8,9 роликові зразки 3, 4 будуть плавно змінювати свої кутові швидкості $\omega_{1}$ і $\omega_{2}$ від $28,55 \mathrm{c}^{-1}$ до $34,89 \mathrm{c}^{-1}$, а далі від $34,89 \mathrm{c}^{-1}$ до $28,55 \mathrm{c}^{-1}$, проходячи кожного разу через $\omega_{3}=31,4 \mathrm{c}^{-1}$. Відносне проковзування обох роликових зразків 3, 4 однакового діаметра залежно від кута $\varphi^{\circ}$ їх провертання в межах кожного оберту буде плавно змінюватися з позитивними і від'ємними своїми знаками від $\varepsilon_{1}=$ $=+18,17 \%$ до $\varepsilon_{2}=-22,44 \%$, а далі від $\varepsilon_{2}=-22,44 \%$ до $\varepsilon_{1}=+18,17 \%$, проходячи кожного разу через ділянки тертя кочення без проковзування при $\varepsilon_{3}=0 \%$ (рис. 3).

У результаті такого кінематичного зв'язку привода 5 з валами 1, 2 для закріплення роликових зразків 3, 4 і присутності двох

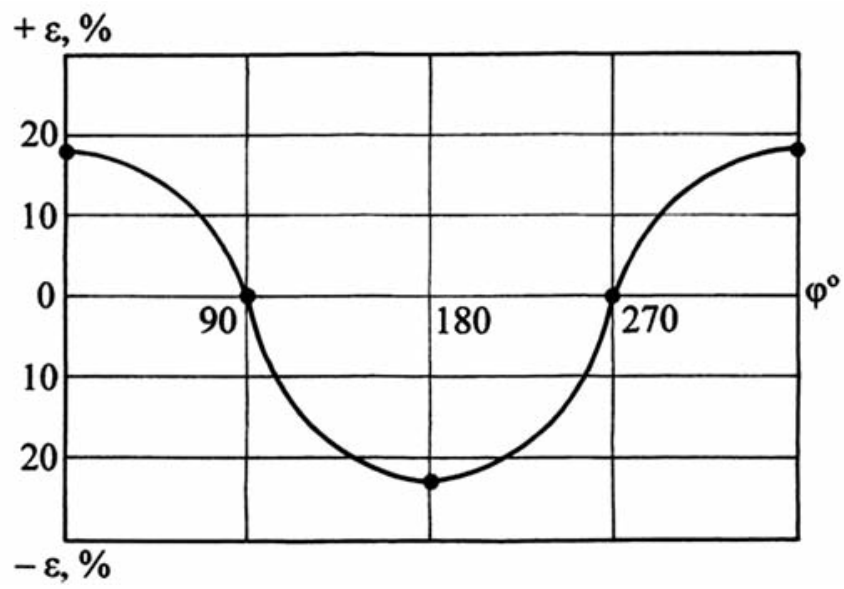

Рис. 3. Залежність зміни відносного проковзування $\varepsilon$, \% роликових зразків однакового діаметра від кута $\varphi^{\circ}$ їх провертання в межах кожного оберту 
пар взаємодіючих між собою ексцентрично закріплених на валах 6, 7, 10 зубчастих коліс 8, 11 та 9, 12 відбуваються плавнозмінні збільшення і зменшення кутових швидкостей роликових зразків 3, 4 після досягнення однакових кутових швидкостей. За цих умов також відбуваються тертя кочення з плавною зміною відносного проковзування на одних ділянках роликових зразків 3, 4 і тертя кочення без проковзування на других їх ділянках, що відповідно забезпечує кінематичні умови взаємодії зубців циліндричних зубчастих коліс вздовж ліній своїх зачеплень 3 різними знаками їх відносного проковзування і значно підвищує точність фізичного моделювання роботи таких зубчастих передач в приводах друкарського обладнання [8, 9].

\section{Список використаної літератури} $155 \mathrm{c}$. Г. К. Трубин. - М. : Машгиз, 1962. - 404 с.

\section{Висновки}

1. Здійснена модернізація машини тертя при використанні в її приводі двох пар ексцентрично закріплених на своїх валах зубчастих коліс, що забезпечує плавнозмінне збільшення і зменшення кутових швидкостей обох роликових зразків однакового діаметра.

2. Тертя кочення 3 плавнозмінним відносним проковзуванням роликових зразків на одних ï ділянках і тертя кочення без проковзування на других ділянках забезпечує кінематичні умови взаємодії зубців циліндричних зубчастих коліс вздовж ліній своїх зачеплень з різними знаками відносного проковзування і значно підвищує точність фізичного моделювання роботи таких зубчастих передач в приводах друкарського обладнання.

1. Хрущов М. М. Лабораторные методы испытания на изнашивание материалов зубчатых колес / М. М. Хрущов. - М. : Машиностроение, 1966. -

2. Ясь Д. С. Испытания на трение и износ. Методы и оборудование / Д. С. Ясь, В. Б. Подмоков, Н. С. Дяденко. - Киев : Техника, 1971. - 138 с.

3. Порохов В. С. Трибологические методы испытания масел и присадок / В. С. Порохов. - М. : Машиностроение, 1983. - 184 с.

4. Трубин Г. К. Контактная усталость материалов для зубчатых колес /

5. Гузенко Ю. М. Модернизация машины трения СМЦ-2 для расширения диапазона переменного проскальзывания образцов / Ю. М. Гузенко // Заводская лаборатория. - 1994. Т. 60. № 9. - С. 60.

6. Рещиков В. Ф. Трение и износ тяжелонагруженных передач / В. Ф. Рещиков. - М. : Машиностроение, 1975. - 245 с.

7. Пат. України на корисну модель № 104266. G 01 N 3/56. Машина тертя для випробування матеріалів зубчастих передач / Ю. М. Гузенко; НТУУ «КП।». - Заявл. 28.05.2015; Опубл. 25.01.2016. - Бюл. № 2, 2016. - 5 с.

8. Тюрин А. А. Печатные машины-автоматы / А. А. Тюрин. - М. : Книга, 1980. $-416 \mathrm{c}$.

9. Друкарське устаткування : Підручник / Я. І. Чехман, В. Т. Сенкусь, В. П. Дідич, О. В. Босак. - Львів : УАД, 2005. - 468 с. 


\section{References}

1. Hrushhov, M. M. (1966). Laboratornye metody ispytanija na iznashivanie materialov zubchatyh koles [Laboratory test methods on wear of materials of gear wheels]. Moscow: Mashinostroenie [in Russian].

2. Jas', D. S. \& Podmokov, V. B. \& Djadenko, N. S. (1971). Ispytanija na trenie $i$ iznos. Metody $i$ oborudovanie [Test the friction and wear. Methods and equipment]. Kiev: Tehnika [in Russian].

3. Porohov, V. S. (1983). Tribologicheskie metody ispytanija masel i prisadok [The tribological test methods of oils and additives]. Moscow: Mashinostroenie [in Russian].

4. Trubin, G. K. (1962). Kontaktnaja ustalost' materialov dlja zubchatyh koles [Contact fatigue of materials for gears]. Moscow: Mashgiz [in Russian].

5. Guzenko, Yu. M. (1994). Modernizacija mashiny trenija SMC-2 dlja rasshirenija diapazona peremennogo proskal'zyvanija obrazcov [The modernization of the machine friction SMC-2 to extend the range of AC slip samples]. Journal of Zavodskaja laboratorija - Factory laboratory, 9, 60 [in Russian].

6. Reshchikov, V. F. (1975). Trenie i iznos tjazhelonagruzhennyh peredach [Friction and wear of heavy loaded gear]. Moscow: Mashinostroenie [in Russian].

7. Huzenko, Yu. M. Mashyna tertia dlia vyprobuvannia materialiv zubchastykh peredach [Friction machine for tests of materials of gears] // Patent № 104266. G 01 N 3/56. Publish 25.01.2016.

8. Tyurin, A. A. (1980). Pechatnye mashiny-avtomaty [Automatic printing machines]. Moscow: Kniga [in Russian].

9. Chekhman, la. I. \& Senkus, V. T. \& Didych, V. P. \& Bosak, O. V. (2005). Drukarske ustatkuvannia [Printing equipment]. Lviv: UAD [in Ukrainian].

В статье рассматривается модернизированная машина трения повышенной точности испытания материалов зубчатых передач. Суть модернизации такой машины трения решается использованием в ее кинематике между приводом и роликовыми образцами одинакового диаметра двух пар эксцентрично закрепленных зубчатых колес. В результате отмеченной кинематической связи обоих роликовых образцов происходит плавное увеличение и уменьшение их угловых скоростей на одних участках с достижением одинаковых угловых скоростей на других участках. В это время происходит трение качения с изменением относительного проскальзывания на одних участках роликовых образцов и трение качения без проскальзывания на других участках. Эти режимы трения обеспечивают кинематические условия взаимодействия зубьев цилиндрических зубчатых колес вдоль линий своих зацеплений с разными знаками проскальзывания. Соответственно, при этих условиях значительно повышается точность физического моделирования работы таких зубчатых передач в приводах печатного оборудования. 
Ключевые слова: машина трения; испытание материалов; зубчатая передача; угловая скорость; роликовый образец; трение качения; трение качения с относительным проскальзыванием.

The article discusses the upgraded friction machine with high precision testing of gears materials. The essence of the modernization of such friction machine is solved using in the kinematics between the drive and rollers samples of the same diameter of two pairs of eccentrically fixed gears. As a result of the mentioned kinematic connection of both rollers samples there is a smooth increase and decrease of their angular velocity in some areas while achieving the same angular velocities in the other areas. At the same time, the rolling friction occurs with a variable relative slippage in some areas of rollers samples and the rolling friction without slipping in the other areas. These friction modes provide the kinematic conditions of engagement of teeth of spur gears along the lines of their links with different signs of slippage. Accordingly, under these conditions, the accuracy of physical simulation of work of gears in drives of printing equipment significantly increases.

Keywords: friction machine; materials testing; gears; angular velocity; roller samples; rolling friction; rolling friction with the relative slippage. 